\title{
dossier | FAKE NEWS: \\ emotion, belief and reason in selective sharing in contexts of proximity
}

Copyright (c) 2019 SBPjor / Associação Brasileira de Pesquisadores em Jornalismo
JOÃO CARLOS CORREIA

University of Beira Interior, Covilhã - Portugal

ORCID: 0000-0002-6317-9007

PEDRO JERÓNIMO

University of Beira Interior, Covilhã - Portugal

ORCID: 0000-0003-1900-5031

ANABELA GRADIM

University of Beira Interior, Covilhã - Portugal

ORCID: 0000-0001-6968-1957

DOI: 10.25200/BJR.v15n3.2019.1219

Received on: 29/03/2019 | Approved on: 20/09/2019

\begin{abstract}
This text addresses the phenomenon of so-called fake news in the new media ecosystem, namely in contexts of increasing influence of populist discourse and action, such as Brazil, the UK, the USA, Italy, among others. It does so by way of some characteristics already implicit in the limited effects theory: a) fake news involves, in a specific way, the participation of its receivers in disseminating and sharing it; b) producers/consumers (prosumers) are involved in contexts of proximity that facilitate selective exposure, perception, and memorization; c) these phenomena are joined by another (selective sharing): the stakeholders share ideas they agree with more intensely. Information bubbles reinforce existing beliefs and predispositions; d) the phenomenon is increased in contexts of proximity, be it geographical proximity provided by regional media or thematic and ideological proximity shared in online groups. Despite this, there is a difference between contexts of proximity in traditional communities and mechanisms of propaganda that have a significant level of organization and ideological polarization.
\end{abstract}

Key words: Fake news. Limited effects. Contexts of proximity. Regional media. Selectivity. 


\section{FAKE NEWS: emoção, crença e razão na partilha seletiva em contextos de proximidade}

RESUMO - Este texto aborda o fenômeno das chamadas fake news no novo ecossistema midiático, nomeadamente em contextos de aumento da influência do discurso e das ações populistas, como Brasil, Reino Unido, EUA, Itália entre outros, através de algumas características, já implícitas na teoria dos efeitos limitados: a) as fake news implicam, de um modo especial, a participação dos seus receptores na sua divulgação e dispersão; b) os produtores/consumidores (prosumers) estão envolvidos em contextos de proximidade que facilitam a exposição, percepção, memorização seletivas; c) a estes fenômenos acrescenta-se outro (partilha seletiva): os stakeholders compartilham com mais intensidade as ideias com que estão de acordo. As bolhas de informação reforçam crenças e predisposições já existentes; d) o fenômeno agrava-se em contextos de proximidade, seja esta a proximidade geográfica e temática proporcionada nos media regionais, seja a proximidade temática e ideológica partilhadas nos grupos online. Apesar disso, há uma diferença liminar entre os contextos de proximidade em comunidades tradicionais e os mecanismos de propaganda com forte índice de organização e mobilização ideológica.

Palavras-chave: Fake news. Efeitos limitados. Contextos de proximidade. Media regionais. Seletividade.

\section{FAKE NEWS: emoción, creencia y razón en el intercambio seletivo en contextos de proximidad}

RESUMEN - Este texto aborda el fenómeno de las llamadas fake news en el nuevo ecosistema mediático, a saber, en contextos de creciente influencia del discurso y la acción populistas como Brasil, EE.UU., U.K., Italia, entre otros, mediante algunas características implícitas en la teoria de los efectos limitados: a) las fake news implican, de modo especial, la participación de sus receptores en su divulgación y dispersión; b) los productores / consumidores (prosumers) participan en contextos de proximidad que facilitan la exposición, la percepción y la memorización selectiva; c) a estos fenómenos se añade otro (compartición selectiva): los stakeholders, quienes comparten con más intensidad las ideas con que están de acuerdo. Las burbujas de información refuerzan creencias y predisposiciones ya existentes; d) el fenómeno se agrava en contextos de proximidad, es decir, la proximidad geográfica y temática proporcionada en los medios regionales, sea la proximidad temática y ideológica compartida en los grupos online. Apesar de ello, hay una diferencia entre los contextos de proximidad en comunidades tradicionales y los mecanismos de propaganda con fuerte índice de organización y movilización ideológica.

Palabras clave: Fake News. Efectos limitados. Contextos de proximidad. Medios regionals. Selectividad.

\section{Introduction}

Fake news is generally accepted as a new phenomenon associated with new technologies and the digital ecosystem. However, false new stories have existed for centuries, though they have been classified differently: as propaganda, misinformation, yellow journalism, conspiracy theories, or unconfirmed rumors. Several examples record this recurrence throughout the history of journalism: the Timisoara massacre during the Romanian Revolution, with its detailed descriptions of the bloody events that occurred there, particularly surprised the inhabitants of the Romanian city who 
continued to live relatively quiet daily lives, and received news of their radical extermination with some amazement. The disinformation campaign conducted by the Bush Administration, which enabled the US to start the Iraq War (Castells, 2013, p. 232-260), is a more recent example, although it took place in a context that was still different from the present one. In further studies, it will be worth tracing out categories for these possibilities, because the concept, just like populism, covers a diverse panoply of problems. For example, Ferreira (2018), citing Wardle (2017), points out an interesting set of types:

\footnotetext{
-Satire or parody: not intended to cause harm, but with the potential to deceive;

- Misleading content: misleading use of information to frame a problem or person;

- Imposter content: when genuine sources are represented;

- Manufactured content: new content that is $100 \%$ fake, designed to deceive and harm;

- False connection: when headlines, images or captions do not support the content;

- Fake context: when genuine content is shared with fake contextual information;

- Manipulated content: when genuine information or images are manipulated to deceive (Ferreira, 2018, p. 142).
}

It is not a categorization of fake news or misinformation phenomena, but rather identifies, in a way that we find extremely productive, "different performance repertoires" in fake newsmaking that deserve to be analyzed. Zamith et al. (2019, p. 9-10), approach the concept in a study on clickbait, in which they argue that this kind of title "can exploit sensationalism, provocative content, rumors, scandals, tragedies, fake news and even the supernatural, [and] aims for spreadability, especially on social networking platforms, to reach more people and meet the expectations of a business model based on digital advertising". The same study presents exaggeration, deception, speculation, advertising and entertainment as categories of clickbait.

Authors such as Gelfert (2018) attempt a phenomenology of fake news, requirements for such a definition including the existence of false claims devised with a purpose (by design); the existence of a mock journalistic statement, that is, the appearance of news; and finally the fact that the presentation of false or misleading claims as news is deliberate, that is, involving human planning even if it includes automated robotic execution. Other authors (Müeller \& Sousa, 2018; Coady, 2006; Gelfert, 2013; Muller, 2016) insist on a distinction from rumors, as something that passes through many 
people who spread it and which has an unofficial status at the time and place in question. In other words, there is a quantitive requirement - a number of what we call shares, propagation, or virality - and a qualitative requirement for informality. This distinction from rumors seems interesting and equally productive. However, under the current conditions of producing fake news, it is questionable. First of all, the spread, sharing and virality, or the exposure value of the news, its potential to attract viewers and followers, are values of fake news itself. In addition, new production and reception conditions make it difficult to delimit backstage and frontstage, essential for delineating a context of informality versus a context of formality: the place of speech, the conditions for defining legitimacy. The place of speech is essential for recognizing the informal versus formal dichotomy. Indeed, the production and reception of fake messages is often materialized through social networks in informal contexts of collaborative co-production where ascertaining authorship in the classical sense is more difficult.

We primarily aimed to deal with the new wave triggered by Donald Trump's victory, thee Brexit referendum, the elections in Brazil, and the rise of the alt right, ${ }^{1}$ identifying some features that involve public participation, the customization or personalization of shared content in proximity contexts, and selectivity in reception and sharing. We do not believe that this will exhaust the fake news issue, but it is intended to identify some traits that deserve reflection.

The fake news associated with the new digital ecosystem ${ }^{2}$ involves the participation of its recipients in its dissemination and dispersal. It results from a radically new attitude towards audiences that has emerged in recent years, coupled with the expansion of new digital technologies, social media and user-generated content (Fishkin et al., 2015, p. 1030).

Active advocates of this new paradigm, authors such as Rosen (2006, June 30), have expressed their belief that changes in the relationship between journalists and audience have involved a shift from the old one-to-many broadcasting system to a manyto-many conversational system. Obviously, these changes have included social media, online commenting systems, new distribution channels, a new model in which consumption itself is no longer separate from production, which has been joined by blog platforms, storytelling platforms, and calling services that are simultaneously social networks like WhatsApp. 


\section{The fake news and effects theory: exposure, perception, memorization and sharing}

Prosumers (McLuhan \& Nevitt, 1972; Tofler, 1980) are involved in proximity contexts that facilitate selective exposure, perception, memorization, and sharing. As canonically established in the literature, the limited effects theory that defined these concepts above coincided with the 1940 s to 1960 s and culminated with Klapper's work, "The Effects of Mass Communication", a kind of summary of the works by Katz \& Lazarsfeld (1964). According to the established hypothesise, responses to a media message are mediated and influenced by interpersonal relationships within the group. The overall result cannot be attributed to individuals alone. It derives from the network of interactions that take place between people. Media effects are the result of a process of personal influence, which involves pre-existing beliefs in the group. In the book Personal Influence: "The Part Played by People in the Flow of Mass Communication", a "law" of selective memorization was identified: not only did people expose themselves to media content selectively, but they perceived it selectively too, and they tended to memorize essentially the information that best suited their ideas (Klapper, 1960, p. 10-11).

Selective exposure demonstrates only that people are more easily exposed to news they agree with. The hypothesis made an appearance in the limited effects theory, centering on the repeated belief that people who did not expose themselves to messages contradicting their beliefs entrencehed their opinion (Klapper, 1960). It is often used in political communication to explain why certain kinds of electoral rituals (rallies, campaign newspapers, etc.) end up being essentially directed at mobilizing supporters. Stroud (2010, p. 555556) points out that there is evidence that selective party exposure leads to polarization and there is a related symmetrical phenomenon: polarization can lead to partisan political commitment and thus selective exposure. Today, the phenomenon, rather than being an example of the existence of limited effects, can be viewed as an inducer of media effects around the concept of polarization, especially introduced by the Internet, which is seen as producing intolerance and extreme viewpoints (Sunstein, 2009, pp. 2-3; Stroud, 2010, p. 556).

Selective perception only demonstrates that individuals are especially predisposed to perceive what they are accustomed to or to perceive whatever is most convenient for them in terms of obtaining some social or physical gratification. Members of the public 
"are covered and protected by existing predispositions, selective processes, and other factors" (Klapper, 1960, p. 247).

Selective memorization consists of forgetting or memorizing part or all of the message, and concerns acquired predispositions. Levine \& Murphy (1943 as cited in Kappler, 1960) ${ }^{3}$ presented a study that seemed to pre-announce many others of the Cold War, which consisted of distributing material classified as being pro-communist to five colleagues with communist tendencies and five colleagues wieth anti-communist tendencies. During the period followinge contact with the documents, several tests were carried out. Those with a more unfavorable position were found to eincreasingly forget what they had read, while those who had a position consistent with the texts took longer to forget (as cited in Klapper, 1960, p. 26).

\section{Media, platforms and attitudes}

The so-called limited effects theory has been applied to small groupse, as is well known. However, early one, the hypothesis was posed that reinforcement of prior beliefs was rather a powerful cognitive effect. It is possible to resumee research by Katz \& Lazarsfeld (1964) for the fragmented proximity contexts of the digital ecosystem. But (as some authors have argued even in relation to the beginnings of the theory) the existence of previous beliefs and assumptions does not serve as a filter in relation to media effects, but rather as an echo chamber. This is not exactly new, but it is an undervalued and less questioned aspect that has become more evident in social network discussion groups, chats and feeeds.

Noelle-Neumann (2009, p. 154-155) had already warned that even in the "golden years" of limited effects, there were studies refuting the idea of filter and the concept of limitation, demonstrating that groups tend to exercise strong social control over their members and amplifying the strength of their beliefs by alignment with the media. That is, the media confirmed the group's presuppositions, and the groups, in turn, amplified those that were adapted to the group's internal way of thinking. The classical orthodoxy of limited effects itself enshrined in the works of Katz and Lazarsfeld and synthesized in Kapperjá had come to the same conclusion, though placing it in a secondary and almost hidden position in the numerous reports it produced (Noelle-Neumann, 2009, p. 155). However, as groups 
were seen as a filtering element of media effects taken as full, it was not clear that reinforcement itself could be, on the basis of diverse cognitive assumptions, considered a powerful effect.

\begin{abstract}
A large number of studies, some carried out in the laboratory and others in the social world, indicate that persuasive mass communication functions more often as a reinforcing agent than as a change agent. Within a given audience exposed to specific communications, reinforcement or at least constancy of opinion is typically discovered as the dominant effect made; small change, such as small change in the intensity of opinion, is the second most common effect; and conversion is typically the rarest effect. (Klapper, 1960, p. 15).
\end{abstract}

Finally, Gitlin (2002, p. 110-114) considered that the behavioral assumption of a short-term effects-centered psychology served to measure electoral or advertising campaigns, but disregarded longer-term, more complex cognitive effects (as Lazarsfeld himself admitted in footnotes in his articles).

Gitlin later criticized proponents of the limited effects theory, namely Klapper, for considering reinforcement as a minor matter. In fact, "reinforcement is an indispensable element between attitudes and actions", "a configuration (...) that determines in an important way how people perceive or respond to new situations" (Gitlin, 2002, p. 116).

In a global dynamics of attitude formation that involves the intervention of interpersonal group relations, the global effect of messages proceeds in three directions: an activation effect (which transforms latent trends into actual ones), a reinforcing effect (which preserves decisions made, avoiding changes in attitude) and a conversion effect (limited, however, by the fact that those who are most attentive and exposed to election campaign messages are also those who have the most structured attitudes while those who are the most undecided are those who least consume the messages).

This element was taken into account when closed agendas emerged around groups that have similar thoughts, which seems to contradict the democratic idea of expanding the agenda. The new ecosystem makes it possible to place a new emphasis to information that coincides with their previous beliefs, so that media effects translate primarily into reinforcement. Preference-based reinforcement is produced by three related phenomena:

a) The motivation among media platforms to funnel information to ideologically fragmented audiences (Maddow, 2010) or even to specific individuals as in the case of social media (Scheufele \& Nisbet, 2002) with a view to creating more attractive advertising environments; 
b) The tendency among audience members not only to select and interpret information consistent with previous beliefs, but also to rely on very endogenously selected online social networks, which are often compared to echo chambers (Sunstein, 2009), that still further narrow the range of subjects available and their interpretation;

c) With networks comes a new interface between media and audiences, such as the results provided by search engines (Ladwig et al., 2010) or by personalized news aggregators that drive more and more information, that is, information increasingly chosen according to the group's previous assumptions.

Over time, we are increasingly witnessing the emergence of numerous issues in which the hybrid construction of public debate manifests itself, as it ewith euthanasia, gay marriage, and numerous immigration matters. Generally triggered by news and media events: news sharing and dissemination take place simultaneously through traditional and social media, putting increasing pressure on debate and legislative production. However, while the combination of political and communication elements with regard to these issues demonstrates how the formation of public opinion in a hybrid system has changed considerably, there are still, within these intricate communication flows, media organizations and powerful political actors who have influence, even if it is occasionally flanked by the disintermediation of traditional gatekeepers (Splendore, 2018, p. 409; Barisione \& Ceron 2017, p. 77). Themes are characterized by a high level of polarization. This polarization is not only caused by social media, but by the multiplication and fragmentation of media channels (Boxell et al., 2017). Finally, the polarization of opinion (for and against vaccination, for and against immigration, etc.) does not, in the end, correspond to the need for the stories that circulate in the media to become simplified, projecting yet another arena of games, of gains and losses, of failures that produce scandals, than a true deliberative discussion (Gurevitch et al., 2009, pp. 172; 175).

Recently, it was found (Splendore, 2018, p. 417; Ferreira, 2018, p. 1429) that many of the messages that abound on social networks reflect agendas of groups that narrow the range of topics and angles from which those themes are addressed, leading to ethnonationalism, populism, and the polarization and grouping of political life.

For example, debates such as those surrounding lus Soli (the law that attributed Italian nationality to those born in Italy or to children who completed their school education in Italy) were the final straw that triggered a complex political process between the Center-Left and the 
Five Star Movement ${ }^{4}$ in that country, which resulted in strengthening the leadership of opinion by the latter and was associated with protest movements that particularly mobilized people on the street and social movements, with a vast use of digital media.

The situation created led Prime Minister Paolo Gentilone to postpone the debate, since adequate conditions were not met for it to be held. Interestingly, the decision was presented as a victory of the people, as was announced by the opposition, and Salvini ${ }^{5}$, through social networks, was the protagonist in claiming victory for the Northern League and all those who intervened online. The opposition turned out to be particularly well orchestrated by parties that did not support the law, which flooded their networks with news of foreign crime, against an emotional and dramatic backdrop. In June 2017 there were at least 217,000 public tweets and posts on the topic, most of which appeared on the opening day of the parliamentary debate, with over $60 \%$ of comments being negative, especially the result of a media storm around \#NOiussoli (no to the law of the right to nationality) (Splendore, 2018, p. 412). Fake news came to the center of the debate, especially as it emerged as a strategy of delegitimizing opponents. Many of the fake news stories were not about the law, but about the law's supporters, attributing to them characteristics that hurt their credibility.

In the case of Brazil, recent studies (Ferreira, 2018, p. 139) find two fundamental pieces of data: the capacity for emobilization (engagement) of fake news is up to three times greater than for traditional media content and, in the case of the two highest rated candidates in surveys and opinion pollse, on opposite sides of the spectrum, false content accounts for more than half of engagement and mobilization, with Bolsonaro and Haddad reaching higher relative values.

In the UK, prior to the Brexit referendum, out-of-context or simply false arguments about the costs of refugees' entry or stays or their weight in the welfare system, driven by an anti-Europe crusade by tabloids such as The Sun and the Daily Mail, influenced the debate and its outcome (Harding, 2017 as cited in Ferreira, 2018) ${ }^{6}$.

Contrary to what one might think, Portugal, although not attracting the same attention as the United States, the UK, Italy and Brazil, is not immune to the phenomenon, and is constantly associated with the mobilization of news values related to inversions, scandals and transgressions that arouse attention for hurting social, moral or ideological beliefs. 
For example, a case that revolted Portuguese people in late 2017 was based around a video of a man pushing a second homeless man into a dustbin. ${ }^{7}$ This content quickly spread online and was even presented by some media as news. However, some pointed out that the information availabele was "scarce and unreliable". ${ }^{8}$

Something similar happened during the summer of 2017 , at a time associated with the fire crisis in Pedrógão Grande, in the district of Leiria. Word spread Antonio Costa's future as prime minister was hanging by a thread, as the Government was being heavily criticized for its inability to control that natural disaster. The news story, which turned out to be false, was first published in the prestigious EI Mundo and, afterwards, reproduced by Portuguese media. However, no sources were mentioned, notably official sources. Sebastião Pereira was the name of the author, but his true identity could not be ascertained by the Committee of the Professional Journalists Licenses. As for El Mundo, it would clarify the situation by saying that eit was a pseudonym ${ }^{9}$ of a journalist working from Lisbon.

One significant case, as it mobilizes identity issues and may be considered the exemplary ancestor of fake news, is the "Carcavelos Beach Sweep", allegedly held on June 10, 2005 (Portugal Day). According to media reports, there was a sweep that mobilized hundreds of people, who robbed and assaulted anyone that appeared in their path. Its definition as a collective robbery organized by young people from troubled neighborhoods, similar to a phenomenon allegedly occurring in Rio de Janeiro, ${ }^{10}$ was tacitly accepted. The event caused terror on the beach and generated a feeling of insecurity. The vast majority of those involved in the sweep were African.

On July 7, Diana Andringa, journalist at RTP and former President of the Union of Journalists, interviewed the commander of the Public Security Police's Metropolitan Command of Lisbon, Oliveira Pereira, who said that "there was no sweep in the sense of an organized group that swept along the beach". Oliveira Pereira added: "I knew this about an hour later. However, when I wanted to make a transmission to clarify the statement, I never managed to".

We recover another case, which began in 2010 and focuses on a central issue for a certain definition of Portuguese identity structured around religion and Fatima. "There are complaints of dog mistreatment in Fátima", the Diário de Notícias newspaper reported, due to the alleged poisoning of the animals right at the Fátima Sanctuary (Carmo, 2010, May 28). At the time, several photos circulated online that attested to 
the truth of the story, and a Facebook group was even set up for this cause called "Scandal at the Fátima Sanctuary (Killing Innocents!)". Still, it was not clear whether the reported inecidents had actually happened. This issue was repeatedly returned to over the years, until in 2016 the Jornal de Leiria newspaper decided to investigate (Boato de maus tratos, 2016, May 20). This led to the matter being declared as false by those responsible for the Sanctuary - and to a journalistic project that allowed not only contextualized, but also clarified. "The details of the news story/rumor are almost always the same: allegedly someone unspecified would have seen something, and journalists would have been barred when they intended to report on alleged mistreatment and caged dogs", the regional newspaper stated. The new information brough was about the origin of the propagation phenomenon: a blog called Além Douro Digital" that declared itself to be about "information from the northern region of Portugal".

Fake news has been systematically used as a space of intervention in the power struggle. One of the images that circulated quickly on social networks shows Catarina Martins, leader of the Left Bloc, a party associated with the current Portuguese left-wing parliamentary majority, with a circle drawn around her wrist. The picture states that she has a luxury Swiss watch worth 20.9 million euros. The watch cannot be not seen and despite the Left Bloc saying that the news is "absolutely false", the first posting of the image on Facebook resulted in 875 shares.

Following this case, the Diário de Notícias (DN) named and identified several Portuguese websites publishing this type of content, all based in Canada (Pena, 2018, October 21). They share the same IP address and the newspaper found a company that specializes in "website creation and maintenance, redesigns for existing wesbites, page development in a professional and engaging environment, search engine optimization". It is called Forsaken and its owner also supports Trump and Bolsonaro. It was there, for example, where the Left Block leader's watch image was created.

In Portugal, the image was published on the website Right Politics. Through the Right Politics' IP address, DN got to its registration in Canada at H3E Montreal, Quebec, at iWeb Technologies. The same IP address is shared by websites such as The Voice of Reason ( $A$ Voz da Razão), We Don't Want A Left Government In Portugal (Não Queremos Um Governo de Esquerda em Portugal), Fun Video, and Speeding Up. In Santo Tirso, the computer company Forsaken also 
shares the same IP address. Set up in 2014, the company is connected to only one name: João Pedro Rosas Fernandes. The DN reveals that all the fake websites and newsgroups are linked to Portugal on the Web, referred to on a website called Fun Video, the owner of which is João Fernandes. He justifies the spread of lies by his convictions: "Unhappy with the lack of opposing views that existed in the media", he decided to set the political page, "but also to publicize acts of corruption" (Pena, 2018, October 21).

He also declared himself a supporter of Trump and Bolsonaro, "not only for their ideals, but above all because they fight against political correctness and vested interests". According to the investigation, the website has as its "targets" João Galamba, at the time a Socialist Party MP, João Gomes Cravinho, Minister of Defense, Maria Flor Pedroso, Director of RTP, António Costa, Prime Minister, Azeredo Lopes, former Minister of Defense, and Jerónimo de Sousa, Secretary General of the Portuguese Communist Party, among others.

At the same time, one of the most successful fake news sites in Portugal is called Firefighters 24 (Bombeiros 24), but anyone searching for this name on Google finds an ad for a fake service: "24 hour firefighters". If you click on the link instead of an SOS line or a contact, one will find only one website (Pena, 2018, November 11). The page managed to have more than 939,000 shares of its texts on Facebook during the month of October 2018. On Facebook, the page has an even more misleading name, Portuguese Firefighters, and has almost 300,000 followers, not necessarily ideologically polarized sectarians. Firefighters 24 and its counterpart Portuguese Firefighters act as a fake crime newspaper. In their links, several people "lose their lives", others are caught trafficking drugs, others disappear, others pretend to "have cancer", there are tortured and asphyxiated cats, and abused children in hospitals" (idem). According to the DNe, the website's IP address is registered in France on the OVH SAS server in Roubaix. It has an account open with Google's advertising services. The US company does not disclose the contacts or identity of its customers. The same manager of this Portuguese website receives, through the same account, advertising money for a second Portuguese site called Bilbiamtengarsada, which has 286,000 followers on Facebook alone. It is both a means of replicating the misinformation of the fake fire brigade page and a lucrative funding system for the owners of both websites. 
Figure 1 - Some Portuguese fake news sites and their likes on Facebook.

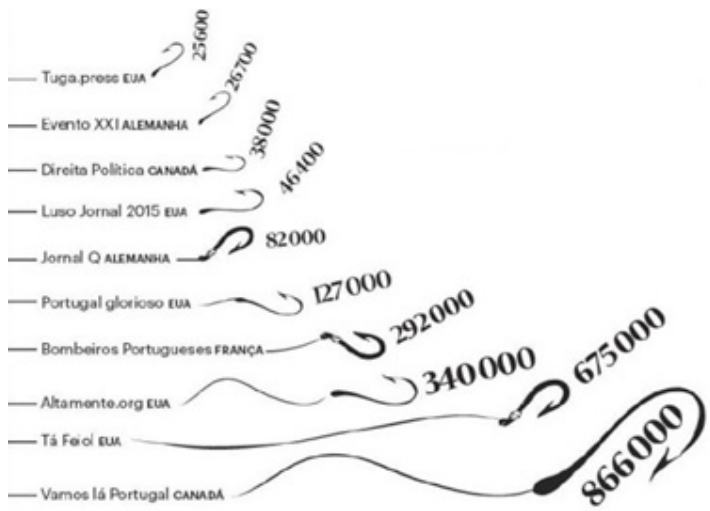

Source: Diário de Notícias (Pena, 2018, November 11)

Analyzing the technique associated with the business model, it is possible to identify that the website Firefighters 24 spreads a specific type of malicious software on its visitors' computers - an affiliate, which allows site administrators to receive money from online sales companies. The website leaves a cookie on readers' computers, which then become linked to Firefighters 24. When that person uses that computer to, for example, buy something from Amazon, the American company learns that its sale was "suggested" by the Portuguese website and pays it a commission (Pena, 2018, November 11).

Despite these circumstances, a nationwide study conducted by Eurobarometer between November 8 and 19, 2018, shows that less than half of Portuguese people (48\%) say they are able to identify misleading or fake news, while the EU average is 58\%. The European Commission considered this situation "worrying", as 2019 was a year in which three electoral acts were to be held in the country - European elections, Madeira regional elections and general elections.

While it is true that the epistemological status of journalistic truth has always been an open topic, since Lippman (Ekström, 2002; Godler \& Reich, 2016), the emergence of this phenomenon has brought particularly complex implications, not least because the debate about the authority of journalism and the existence of fake news has involved actors who were part of the journalistic field, academics and bloggers. Facebook announced that the network would introduce new tools to curb the proliferation of false information. Following an investigation by Buzzfeed, Facebook even blocked several pages, showing the 
importance that networks had in the phenomenon (Splendore, 2018).

Alongside the expansion of agendas brought about by new social movements, digital media are identifying models for identifying themes supported by premodern forms of sociability such as digital hooliganism, bullying, and flaming.

Often there is even a process that culminates in reinforcing a scarce number of hegemonic themes, mutually enhanced through social narratives that gain a transmedia dimension. In many cases, the open network acts as a space for dissemination and interaction between government officials or organic activists and citizens, but also as a tool deliberately directed at mainstream media at the same time as users, generating a mutually reinforcing effect that favours publicity techniques appreciated by public relations because they involve different stakeholders.

This corresponds to an increasingly sophisticated segment bias on the audience side. It is not certain that the democratic expansion of agendas is the only virtuous consequence of new media. Alongside this expansion of agendas and the debate around them, they are also minimized as a result of the basic identification of easily understandable and repeatable elements; it is known that some movements and political actors are fascinated with microblogging platforms such as Twitter or closed groups on Facebook or, more often, on WhatsApp. A social network activist or populist leader seeking legitimacy does not employ discursive logic but rather resorts to oratory expositions, which could be called a flow of ideas. The relationship between assumptions and inferences is replaced by a linking of ideas that rest on mere resemblance, often through association, employing the same characteristic word in two propositions that are not logically related. This method not only avoids the control mechanisms of rational examination, but also makes it psychologically easier for the listener to follow. Of course, it is easy and appealing to make them resonate and amplify them.

In this sense, just as group members better handle, perceive, and memorize messages they agree with, they also share messages they agree with more readily. We may call this effect selective sharing.

\section{Fake news and proximity contexts}

Feke news connects with the concept of proximity. Proximity is usually valued positively, understood as an advantage arising from 
the possible aptitude for business models and citizenship styles based on a close relationship with publics and market segments that enable the creation of specific or autonomous scheduling processes by journalists. Virtuous proximity is a proximity that can be felt in the relationship with interactivity and in changing the model of relationships with the public: public, civic, online, web journalism or proximity online journalism (Jerónimo, 2015) are part of an identical search for a new form of relationship with the public.

However, on the other hand, proximity can be understood as an anachronism, indifferent to cultural, economic and technological transformations and which, due to the institutional dependence of primary definers (Hall, 2002), makes it impossibele to form an autonomous agenda.

Several surveys have shown that upbeat and "happy" discourses about new modes of relationship with audiences do not actually corresepond to journalistic routines, at least in terms of high expectations regarding interactivity (Lewis et al., 2010).

Thus, fake news in the current context also appears to be associated with forms of anachronistic populism that manifest themselves in an attitude of support for a cause rather than pursuit of information.

Taggart (2004, p. 274) introduced the idea of an idealized conception of the community. Typically, this imaginary territory has no future-oriented utopian potential, but rather seeks to reconstruct "what has been lost by the present". On the other hand, this idealization is not based on rational thoughts or historical facts, but rather in rooted emotions that refer to idealizations such as Middle America (Taggart, 2004, p. 97) or "La France Profonde" or "Authentic Portugal" (O Portugal Autêntico). "Usually represented by icons such as the Boston Tea Party in the USA, Guy Fawkes in the UK, Joan of Arc in France, William Tell in Switzerland, or the Constable in Portugal.

In the regional media, too, it is associated with an idea of deep countryside and a "real" country, roots and community that sometimes become an obstacle in the effort to hierarchize and direct autonomously. Notably, in Covilhã, where Re/media.Lab is based ${ }^{12}$, local political debate became the prisoner of two blogs in the years preceding the local elections: Pelourinho ${ }^{13}$ (which seemed to defend the majority party at the Council) and Carpinteira ${ }^{14}$ (Which seemed to conglomerate opposition fringes to the same majority), without any fact-checking, although they often had news material of relevant public interest but lacking serious treatment. On the other hand, the absence of an identifiable editorial officer associated with anonymity easily allowed confusion between 
opinion and fact, rumor, lie and truth, humor, caricature and news.

Proximity contexts are usually reinforced by the attunement of ideas, empathy of feelings, affective ties, and the sharing of common beliefs. Thus, they make it possible for the public to dispense with verifiability at the expense of plausability and group integration.

Today there is a phenomenon of insistent and deliberate lying, and it is found that this lie (in the sense of truly fictionalized facts), even when understood and accepted as such, is absorbed by the supporters of the protagonist favored by the news as legitimate, in a way that reports to mass propaganda. Instead of the drumming, the buzz of tweets on mobile phones resonates.

In other words, "if it is not true, it could be", "if it's not a Muslim, it could be because it's Arab", "if the Brazilian deputy antiBolsonaro did not stage an escape, he could have done so because he is a liar", that is, "if it's not true, it could be" is a type of reaction often detected in supporters who reproduce the lie without confirmation and regardless of its verifiability. Increasingly, the audience cares less if the information they receive is precise and accurate. Using the diverse specialized literature, it is possible to verify the prosperous intensification of individuals and groups, of their own collective or associated agendas, which now have easy ways to distribute out-of-context or false content (Norris, 2011; Ladd, 2012; Nielsen, 2014 as cited in Ferreira, 2018) ${ }^{15}$. The emergence of new production and distribution platforms and the fall in credibility of the traditional press encourage the relativization of the truth, with a direct impact on democratic regimes. Twitter-based research shows that fake news publications experience a greater number of changes in content during dissemination compared to authentic news, leading to the proliferation of cascading information chains, fed by Twitter bots, programmed for political misinformation (Müeller \& Sousa, 2018).

In a context where the production and work relations in newsrooms are not the healthiest, and the conditions of verifiability, reproduction and reception change, we are facing something old in a new context, which changes its impact. That is, it is "fake news" in the sense that even when absurd, the promotion of the leader and his agenda overrides the truth or verifiability in their acceptance by supporters. It is this submissive or even enthusiastic acceptance that ultimately leads to a charismatic power of leaders: lying is part of the mission to indoctrinate. It is not just "wrong" or "inaccurate" news, it is the result of a context in which the distinction between propaganda and journalism is blurred and, is even supported and 
promoted by supporters of the charismatic leader. The problem is no longer a matter of counteracting the truth with a lie but caunteractive "my lie" with "your lie" or "my lie is better than yours."

\section{Fake news and populism}

It follows from the above-mentioned proximity contexts, so often praised for their democratic potential, that they may favor situations of manipulation and propaganda resulting from a desire to be part of the group, and are, in some cases, associated with the charismatic power of totalitarian leaders or the reduction of critical thinking about what is understood to be "ours". Fake news is also associated with a form of proximity that is characterized in particular by the absence of critical distance. This lack of distancing may arise in pre-modern community contexts where regional journalism may become too subservient to primary definers, just as it can arise in postmodern communities (digital groups) where like-minded thought predominates and news is subordinated to ideological proximity without critical distance, becoming viral thanks to agreement with the message and not prior verifiability.

There is, however, a striking difference between the proximity contexts taken on by regional communities merely related by affective ties and the aggressive propaganda mechanisms assumed by highly organized and ideologically mobilized alt right organizations, and with the intensive use of technologies to produce strategically defineed effects. While proximity that is too close to the primary definers is already obstacle enough to the exercise of a certain critical distance, this is further aggravated when the deliberate process of consciousness mobilization instrumentally uses this proximity in a highly personalized and profitable manner. The Guardian and BuzzFeed News named at least 100 websites registered in the small town of Veles, Macedonia, publishing false news in favor of Trump, such as the criminal indictment of his rival and Pope Francis' support for the Republican (Tynan, 2016, August 24; Silverman \& Alexander, 2016, November 3). Pages are a source of profit for their authors with the Google ad monetization system, which pays for each click on a link shared on Facebook. In Portugal, one of the best-known cases is CNoticias.net, which although admits that "news is created by users", "is humorous and fictional content" and "should not be taken seriously or used as a source of information", the truth is that the content created is very highly shared on social networks. The 
domain of that website and sharing by users who have closer proximity to the recipient, are determining factors for the credibility of the content and consequent sharing.

This kind of news results from highly polarized public communication among producers of factually false messages, in a context of radicalization in which propaganda replaces debate and where premodern forms of communication seem to resurface, albeit supported by highly developed technological forms. Fake news demonstrates the ambiguity of the new methods of communication: despite being new, new forms of digital communication reproduce archaic forms of political and communicational relationships found in the history of totalitarian propaganda or in communities where proximity does not allow for open debate.

Thus, fake news in the current context appears associated with forms of anachronistic populism, manifesting itself in an attitude of support for a cause and not a search for information. It is therefore possible to associate fake news with the particular spirit of the time, considering the eruption of social networks and the populism and the general mediation crisis movement that accompany this process.

\section{Conclusions}

We would primarily like to add to this necessarily essayistic and exploratory text some hypotheses resulting from the literature review and case studies that deserve review:

The relationship between social media and this particular style of fake news and the assumed possibility of this relationship being enhanced by personalization/customization, which in turn reinforces proximity and affinity;

Its profound relationship with diverse contexts of proximity, which favor affection, emotion and expressive rationality, with the risks arising from a loss of critical distance;

The ease in making these messages, instruments at the service of simplifying discourse, closely associated with diabolization of the adversary;

The existence of selective sharing behavior, which results from a critical rereading of the limited effects theory, leading to the existence of propagandistic effects in which prior conviction reinforcement is essential for efurther sharing and consequent existence of a cascade of disinformation. 
These intuitions do not challenge the need for a careful categorization that gathers the various kinds of falsehood that news discourse in this context can have: rumor, conspiracy theory, defamatory lie, silence, euphemization of responsibility, which can hardly be neglected in a study about framing.

Finally, it is clear that this exact behavior profile can be seen in disruptive situations: emigration, nationality law, vaccination, euthanasia (Italy); Europe, immigration, foreigners (Brexit); invasion of illegal immigrants, liberal media conspiracy, anti-elite speech (Trump); anti-corruption discourse, gender issues, use and possession of weapons, anti-immigration discourse, minority rights (Trump and, above all, Bolsonaro), which can be identified in Hungary, Poland, Austria, Germany, France, Spain and, peripherally, in Portugal, in disruptive contexts experienced in problematic neighborhoods.

\section{NOTES}

1 Contraction of the alternative right, a term which refers to the far right faction of the United States and some European countries which is characterized by rejection of "classic" conservatism, and the defense of white supremacy, sexism, anti-Semitism and racism in general, focused on an agenda against immigration and the inclusion of immigrants as well as a militant attitude against alternative policies focused on gender studies and the study and defense of alternative lifestyles.

2 Digital ecosystems are composed of companies, people, data, processes, things and traditional and/or digital media that are connected by the shared use of digital platforms. These partner ecosystems are created to enable collaboration and develop synergies among all the parties involved. Jenkins, for exemple, positions digital media around public collaboration and the creation of meaning. Jenkins argues that digital media incentivize those actions and give rise to a participative culture in which consumers and citizens have a larger role to play (Jenkins, 2006; Tussey, 2017, August 21).

3 Levine, J. M., \& Murphy, G. (1943). The learning and forgetting of controversial material. Journal of Abnormal and Social Psychology, 38, 507-517.

4 The 5 Star Movement (stylized as the 5 Star MoVeement; in Italian, MoVimento 5 Stelle or M5S) is an Italian movement self-defined as a non-party, which emerged in 2009 under the leadership of come- 
dian Beppe Grillo, with the purpose of displacing traditional parties to put ordinary citizens in power and establish direct democracy by using the Internet. Ideologically, the M5S is a very complex and diverse party, and is populist, Eurosceptic and anti-systeme.

5 Matteo Salvini is an Italian politician, member of his country's Senate, leader of Lega Nord since December 2013 and Noi Con Salvini ("Us with Salvini") since December 2014. He was also an MEP (2014-2018). He currently holds the position of Deputy Prime Minister of Italy and Minister of the Interior. Salvini is Eurosceptic and nationalist, anti-globalization and one the far right. He is a critic of the European Union (EU), especially the euro, which he has called a "crime against humanity". He strongly opposes immigration and has criticized the mild way in which the EU deals with the issue of people seeking political asylum in Europe. Together with Marine LePen he is one of the great proponents of the right-wing populist movement in Europe, end is responsible for campaigns on social networks with great impact against immigration.

6 Harding, G. (2017). Media lies and Brexit. A Double Hammer-Blow to Europe and Ethical Journalism. In A. White (Ed.) Ethics in the News. Ethical Journalism Network report on challenges four journalism in the posttruth era (11-13). Londres: Ethical Journalism Network.

7 "Vídeo de jovem a empurar sem-abrigo para contento gera indignação", SIC Notícias, December 12, 2017 . Retrieved from https:// sicnoticias.pt/pais/2017-12-12-Video-de-jovem-a-empurrar-semabrigo-para-contentor-gera-indignacao.

8 "O que se sabe sobre o video de jovem a atirar sem-abrigo para o lixo", TVI, December 13, 2017. Retrieved from https://tvi24.iol. pt/sociedade/caixote-do-lixo/o-que-se-sabe-sobre-o-video-dejovem-a-atirar-sem-abrigo-para-o-lixo

9 “'El Mundo' recusa identificar autor de artigos sobre incêndios em Portugal", Diário de Notícias, June 23, 2017 . Retrieved from https://www.dn.pt/media/interior/el-mundo-recusa-identificar -autor-de-artigos-sobre-incendios-em-portugal8586294.html

10 Retrieved by Correia, J.C. (2009). Teoria e crítica do discurso noticioso, p. 165. Covilhã: LabCom.

11 https://alemdourodigital.blogs.sapo.pt/

12 Research project that has the scope of an observatory, laboratory and regional media incubator. 
13 http://pelourinho2013.blogspot.com

14 http://carpinteira.blogspot.com

15 Ladd, J. M. (2012). Why Americans Hate the Media and How It Matters. Princeton: Princeton University Press. Nielsen, R. K. (2014). The Many Crises of Western Journalism: A Comparative Analysis of Economic Crises, Professional Crises, and Crises of Confidence. SSRN. Retrieved from: https://ssrn.com/ abstract=2600863. Norris, P. (2011). Democratic Deficit: Critical Citizens Revisited. Cambridge: Cambridge University Press.

\section{| REFERENCES}

Barisione, M., \& Ceron, A. (2017). A Digital Movement of Opinion? Contesting Austerity through Social media. In M. Barisione \& A. Michailidou (Eds.), Social media and European Politics (p. 77-104). Basingstoke: Palgrave MacMillan.

Boato de maus tratos a cães no Santuário e fotos chinesas voltam a incendiar redes sociais (2016). Jornal de Leiria. Retrieved from www. jornaldeleiria.pt/noticia/boato-de-maus-tratos-caes-no-santuario-efotos-chinesas-volt4193

Boxell, L., Gentzkow, M., \& Shapiro, J. M. (2017). Is the Internet Causing Political Polarization? Evidence from Demographics, NBER Working Papers 23258, National Bureau of Economic Research, Inc. https://doi.org/10.3386/w23258

Cass, R. (2007). Ideological Amplification. Constelattions, 14(2). DOI: $10.1111 / \mathrm{j} .1467-8675.2007 .00439 . x$

Carmo, P. (2010, maio 28). Há queixas de maus tratos a cães em Fátima. Diário de Notícias. Retrieved from www.dn.pt/portugal/centro/ interior/ha-queixas-de-maus-tratos-a-caes-em-fatimal 580369.html

Castells, M. (2013). O Poder da Comunicação. Lisboa: Fundação Calouste Gulbenkian.

Coady, D. (2006). Rumour has it. International Journal of Applied Philosophy, 20(1), 41-53.

Ferreira, R. R. (2018). Rede de mentiras: a propagação de fake news na pré-campanha presidencial brasileira. Observatorio $\left(O B S^{*}\right)$, Special Issue, 139-162. DOI: 10.15847/obsOBS12520181272

Fishkin, J., Kousser, T., Luskin, R.C. \& Siu, A. (2015). Deliberative Agenda Setting: Piloting Reform of Direct Democracy in California. Perspetives 
Ekström, M. (2002). Epistemologies of TV Journalism: A Theoretical Framework. Journalism Practice, 3(3), 259-282. DOI: $10.1177 / 146488490200300301$

Gelfert, A. (2013). Coverage-reliability, epistemic dependence, and the problem of rumor-based belief. Philosophia, 41(3), 763-786.

Gelfert, A. (2018). Fake News: A Definition. Informal Logic, 38(1), 84-117.

Gitlin, T. (2002). Sociologia dos meios de comunicação social: o paradigma dominante. In J. P. Esteves (Ed.), Comunicação e Sociedade (107-151). Lisboa: Horizonte.

Godler, Y., Reich, Z., (2016). How Journalists “Realize” Facts. Journalism Practice, 7(6), 674-689. DOI: 10.1080/17512786.2013.791067

Gurevitch, M., Coleman, S., \& Blumler, J. G. (2009). Political Communication: Old and New media Relationships. Political and Social Science, 625(1). DOI: 10.1177\%2F0002716209339345

Hall, S. (2002). Encoding/decoding. In P. Harris \& S. Thornham (Eds.), Media Studies (51-61). Edimburgh: Edimburgh University Press.

Jerónimo, P. (2015). Ciberjornalismo de proximidade: Redações, jornalistas e notícias online. Covilhã: LabCom Books.

Jenkins, H. (2006). Convergence Culture: Where Old and New Media Collide. New York: New York University Press.

Katz, E., Lazarsfeld, P. (1964). Personal Influence. New York: Free Press.

Klapper, J. (1960). The effects of mass communication. New York: The Free Press.

Lazarsfeld, P., Berelson, B. \& Gaudet, H. (1948). People's choice. New York: Columbia University Press

Lewis, S. C., Kaufhold, K., \& Lasorsa, D. L. (2010). Thinking about citizen journalism: The philosophica and practical challenges of usergenerated content for community newspapers. Journalism Practice, 4(2), 163-179. DOI: 10.1080/14616700903156919

Ladwig, P., Anderson, A. A., Brossard, D., Scheufele, D. A., \& Shaw, B. R. (2010). Narrowing the discourse? Materials Today, 13(5), 52-54. DOI: 10.1016/S1369-7021(10)70084-5

Maddow, R. (2010). Theodore H. White Lecture on Press and Politics [transcript]. Joan Shorenstein Center on the Press, Politics and Public Policy, Harvard University. Retrieved from https://shorensteincenter.org/ wp-content/uploads/2010/11/th_white_2010_maddow.pdf?x78124 
McLuhan, M. \& Nevitt, B. (1972). Take today: the executive dropout. New York: Harcourt Brace Jovanovich.

Müller, F. M. \& Sousa, M. V. (2018). Fake News: um problema midiático multifacetado. VIII Congreso Internacional de Conocimiento e Innovación (Habitats de Innovación y Economia del Conocimiento: una apuseta para el futuro. Retrieved from http://proceeding.ciki. ufsc.br/index.php/ciki/article/view/511/261

Müller, F. M. (2016). Definindo boato. Veritas (Porto Alegre), 61 (2), 425-436.

Noelle-Neuman, E. (2009). Os efeitos dos meios de comunicação na pesquisa sobre os seus efeitos. In J. P. Esteves (Ed.), Comunicação e Sociedade (153-162). Lisboa: Livro Horizonte.

Pena, P. (2018, October 21). Como funciona uma rede de notícias falsas em Portugal. Diário de Notícias. Retrieved from www.dn.pt/edicaodo-dia/21-out2018/interior/como-funciona-uma-rede-de-noticiasfalsas-em-portugal 10046731 .html?target=conteudo_fechado

Pena, P. (2018, November 11). Fake news: sites portugueses com mais de dois milhões de seguidores. Diário de Notícias. Retrieved from www.dn.pt/edicao-do-dia/11-nov2018/interior/fake-news-sitesportugueses-com-mais-de-dois-milhoes-de-seguidores $10160885 . \mathrm{html}$

Rosen, J. (2006, June 30). The People Formerly Known as the Audience. The Huffington Post. Retrieved from www.huffingtonpost.com/jayrosen/the-people-formerly-known_1_b_24113.html?guccounter=1

Splendore, S. (2018). Communicative activism and political impasse: the changing media system in the context of fake news and populism, Contemporary Italian Politics, 10(4), 407-420. DOI: 10.1080/23248823.2018.1544356

Scheufele, D. A., \& Nisbet, M. C. (2002). Being a citizen online: New opportunities and dead ends. The International Journal of Press/ Politics, 7 (3), 55-75.

Silverman, C. \& Alexander, L. (2016, November 3). How Teens In The Balkans Are Duping Trump Supporters With Fake News. BuzzFeed News. Retrieved from www.buzzfeednews.com/article/craigsilverman/howmacedonia-became-a-global-hub-for-pro-trump-misinfo

Stroud, N. J. (2010). Polarization and Partisan Selective Exposure. Journal of Communication, 60(3), 556-57. DOI: 10.1111/j.14602466.2010.01497.x

Sunstein, C. (2009). Republic.Com 2.0. Princeton: Princeton University Press.

Taggart, P. (2004). Populism and representative politics in contemporary Europe. Journal of Political Ideologies, 9(3), 269-288. 
Tofler, A. (1980). A terceira onda. Rio de Janeiro: Recorda.

Tynan, D. (2016, August 24). How Facebook powers money machines for obscure political 'news' sites. The Guardian. Retrieved from www. theguardian.com/technology/2016/aug/24/facebook-clickbaitpolitical-news-sites-us-election-trump

Tussey, E. (2017, August 23). Digital Media and Convergence Culture. Oxford Bibliographies. Retrieved from http://69.63.132.71/view/ document/obo-9780199791286/obo-9780199791286-0269.xml

Zamith, F., Fonseca, A. A., Botão, A., Ramos, A., Reis, A. I., Demeneck, B. H., ... Filho, W. J. S. (2019). O clickbait no ciberjornalismo português e brasileiro: o caso português. In A. I. Reis, P. Jerónimo, F. Zamith \& H. Bastos (Eds.). Ameaças ao Ciberjornalismo - Atas do VI Congresso Internacional de Ciberjornalismo (p. 7-29). Porto: Observatório do Ciberjornalismo.

Wardle, C. (2017). Information Disorder. Toward an interdisciplinary framework for research and policy making. Strasbourg: Council of Europe.

\section{FUNDING}

This paper was developed within the framework of $\mathrm{Re} /$ media. Lab - Laboratory and Incubator of Regional Media, a research project cofinanced by the PT 2020 Program, under the CENTRO 2020 Program and the European Union through the FEDER (CENTRO-01-0145-FEDER031277).

JOÃO CARLOS CORREIA. Associate Professor with agregação at the University of Beira Interior, head researcher of Re/media.Lab and editor of the Estudos em Comunicação journal. Email: jcorreia@ubi.pt

PEDRO JERÓNIMO. Researcher at the University of Beira Interior (LabCom.IFP), executive coordinator of $\mathrm{Re} /$ media.Lab, editor of the Estudos de Jornalismo journal (SOPCOM) and also researcher at CECS (University of Minho). Email: pj@ubi.pt

ANABELA GRADIM. Assistant Professor with agregação at the University of Beira Interior, co-head researcher at Re/media.Lab and co-editor of Estudos em Comunicação journal. Email: anabela.gradim@labcom.ubi.pt 